\title{
Voices against Violations: Eugenics in Literature
}

\author{
Masami Usui
}

\begin{abstract}
Contemporary literature is seriously confronted with the unavoidable multilayered conflicts and violations in the age of globalization. Both Kazuo Ishiguro (1956-) and Yuko Tsushima (1947-2016) have been challenging to express these conflicts that have occurred repeatedly and threatened human lives in the twentieth and twenty-first centuries. With a common Japanese background, both writers have been obsessed with the consequences of World War II and the devastated waste land crashed by atomic bombings as an archetypal image of victimized Japan in their minds. Furthermore, they been consistently witnessing and considering the contemporary violent and chaotic incidents on the globe. Because of their consciousness of the past devastation, both Ishiguro and Tsushima have possessed the keen insight into the contemporary issues. In their literature, both of them fight against whatever degrades the dignity of life and especially they focus on eugenics as its most notorious example in human history which mercilessly changed the destiny of innocent people.
\end{abstract}

Index Terms-Global literature, World War II, atomic bombing literature, eugenics.

\section{INTRODUCTION}

Globalization in literature is a natural trend in this century. Both Ishiguro and Tsushima can be defined as global writers who aim at expressing the universal themes and manipulating the voices against violations. They have undergone and witnessed the rapid transfiguration of the political, economic, legal, social, and cultural spheres beyond the borders of nations in the twentieth and twenty-first centuries. In this borderless world, however, there appears another endless devastations, strives, and conflicts. Those catastrophes range from the political, religious, economic, and nuclear wars to the natural disasters such as earthquakes, tsunamis, floods, and hurricanes.

For Ishiguro and Tsushima, those transfigurations and catastrophes are what to challenge in order to respect the dignity of human life. Those catastrophes are more or less related to eugenics that threaten human lives and self-consciousness. Voices against violations, which were especially caused by eugenics, are necessary to reexamine. Literature has a potentiality to solve the conflicting issues that are the unrecorded and untold stories.

Manuscript received September 12, 2016; revised December 9, 2016. This paper is one of the products of Masami Usui's five-year (2014-2018) project entitled "Passage to the Borderless Intellectual Property: In Search for Coexisting Discourse of Global Culture and Literature" (No.26370301) with the Grant-in-Aid for Scientific Research (c) by Japan Society for the Promotion of Science.

Masami Usui is with the Doshisha University, Karasuma-Higashiiru, Kamigyo, Kyoto, Japan 602-8580 (e-mail: musui@mail.doshisha.ac.jp).

\section{THE CROSSROAD OF ISHIGURO AND TSUSHIMA}

\section{A. Ishiguro's Revolt Against Violations}

In Ishiguro's psychology, there always exists the postwar devastated landscape of Nagasaki by the dropped atomic bombings at the end of World War II. Born and raised in his infant days in Nagasaki during the postwar period, Ishiguro has been obsessed with this indirect yet family experiences. As a writer, Ishiguro has described a collective memory of these experiences. The, landscape and its meaning of Nagasaki and World War II motivates him to write his novels such as A Pale View of Hills (1982) and When We Were Orphans (2000). Because of this atomic bombing-related background, Ishiguro has been challenging whatever caused the catastrophes of human lives and deprived them of a dignity of life itself. His latest two novels, Never Let Me Go, (2011) [1] and The Buried Giant (2015) [2], are remarkable examples to examine the contemporary catastrophes and controversial issues.

Ishiguro's Never Let Me Go is set up in modern England, yet the scientific development overtakes our contemporary ones. This novel is veiled by Ishiguro's cynicism that a sort of manufacture to producing the wholesome clones for the sick people. As atomic bombings and nuclear weapons destroy humans mercilessly, clone production neglect and even, from the very beginning, destroy the lives of clones. Those clones are orphans and homeless without a dignity of life for themselves. Their lives and meanings of existence are moreover, entirely rejected and ignored. In this novel, this clone production and imprisonment is compared with the Holocaust and its inhuman treatment of the oppressed people.

Under the well-schemed veil of Mediaeval mythology of post King Arthur England, Ishiguro's latest novel The Buried Giant makes a more subtle implication of the inhuman treatment of the all oppressed people that reflect our contemporary people's memories of modern and contemporary historical incidents. Though being offenders and assailants themselves, the protagonists suffer such ongoing symptoms a cognitive impairment, Alzheimer's dementia, segregation, and poriomania. This novel, therefore, possesses the hidden message of revolt against violations represented by the Holocaust, a mass murder, and all the violations to the weak people including women, children, handicapped, and the elderly.

Ishiguro's revolt against violations is the core of his latest novels that retells the hidden stories and messages. The history lesson from Nagasaki atomic bombings has not been widespread, so that Ishiguro plays a role to revive and revise the lesson in a form of fiction.

\section{B. Tsuchima's Resolt against Violations}

Unlike Ishiguro who was born after World War II and spent 
most of his life in England, Yuko Tsushima witnessed and experienced the postwar Japanese lives and values during the period of conflicts between the wartime wrongly-input ideology and the postwar rapidly-liberated ideology. Her personal memory is the ground of the collective memories. In her wide range of creative activities since her young days, Tsushima focuses especially on women's lives and those of the oppressed minorities. Since the Great Earthquake and Tsunami and Fukushima Nuclear Plant hazard in 2011 - named as $3 / 11$ - Tsushima was active and prolific in writing her novels with her strong will against violations till her death in 2016. Tsushima's Yamaneko Domu [Wild Cat Dome] (2013) [3] and Karino Jidai [The Age of Hunting] (2016) [4] as her last novel are set up in modern and contemporary Japan that includes the critical conditions before and after World War II.

Both novels presents to us a series of once-concealed yet gradually-revealed stories of the "unqualified" people that the society cruelly names and violates; single-mothers and their children, handicapped people, colored races, gays, and the elderly. Coined as a literature of 3/11, Yamaneko Domu portrays the postwar orphanage of children as well as that of Japan itself; especially its transformation during the period the economic development and of the recovery of a living standard and a cultural level, and finally its radical yet natural revolt against nuclear plants in our contemporary society.

As Ishiguro employs the myth of Mediaeval hero and its heroism as the wrong ideological figures, Tsushima's Karino Jidai encodes unqualifiedness of ideology by introducing Aktion T4 and Hitlerjugent, Hitler Youth, which was founded in 1926 and visited Japan in 1938. Memory plays a leading part to date way back to the prewar period retrospectively and discovers how humans can be easily misled by wrong ideology. Children's innocence to welcome and adore those young Hitlers during the war period is revealed as the unforgettable memory and wound in their adult days in postwar Japan. History creates a legendary heroism that confuses and misleads the human consciousness and victimizes wholesome psychology as well as physique of human beings.

Tsushima's revolt against violations represents her everlasting quest for the significance of life of the voiceless people. In Tsushima's fiction, the once-misled path is not easily recovered, yet it certainly leaves the deep scar in personal and collective memories.

\section{Voices against Violations}

Both Ishiguro and Tsushima cunningly advocate the wrongly-input and undoubtedly-inherited ideology. As Yugin Teo in Kazuo Ishiguro and Memory manipulates it in his analysis of Ishiguro's works, Paul Ricoeur's Memory, History, Forgiveness "examines a form of collective forgetting that concerns a national imperative to ignore crimes committed in the past" [5, p. 55]. This theory is unconsciously employed by our contemporary writers including Ishiguro and Tsushima. The voices against violations in literature are what both Ishiguro and Tsushima as contemporary writers are confronted with and what they examine and reconstruct as the inevitable challenge in order to reconstruct the silenced, misled, and forgotten memories and stories.

\section{SILENCED AND FORGOTTEN MEMORIES IN ISHIGURO'S NEVER LET ME GO AND THE BURIED GIANT}

\section{A. Memories, Violations, and Victims}

In Ishiguro's works, memories are usually the most significant factor to tell and retell the stories. Ishiguro's memory of World War II is not based on a direct experience, yet it is virtually connected with his family background before his family's migration to England in postwar era; the prewar strives and stories that are partially concealed and dramatized as the shadow of the real world. In a cynical slant on this prewar to postwar condition, both Never Let Me Go and The Buried Giant examine the brutal actions that were once faced with the critical situation, carefully reflected and reconsidered as faults, yet repeatedly occur in a daily basis on the globe, being reminiscent of the prolonged crisis ranging from the Holocaust to our contemporary crisis.

The physical and psychological conditions of the clones in Never Let Me Go are the same as those of the evacuated in the Holocaust. Both of them are entirely deprived of their sense of dignity of life. Those imprisoned clone children are paradoxically opposed to those oppressed people in the Holocaust because the clone children should be healthy in terms of eugenic. Similarly, The Buried Giant plunges into this critical environment that violate all the oppressed people including the victims as well as the former invaders.

\section{B. Never Let 'We' Go}

The clone production in Never Let Me Go is based on a different form of eugenics under the name of medical transplantation. Clone children are regenerated from cells and they are nourished for the future organ donations for people of dominant traits and genes. As far as clones are the living of recessive traits and genes, they are worthless and disposable. At the end of the novel, the protagonist Kathy $\mathrm{H}$ and Tommy her beloved survivor after three donations were informed of the dangerous problems of clone donations. The former principal Miss Emily explained to Kathy $\mathrm{H}$ and Tommy that they are just "Shadowy objects in test tubes" [1, p. 256]. The idealized education and treatment of clones was over and Hailsham as an elite school for clone children was closed when what is named "the Morningdale scandal" largely influenced the public.

It concerned a scientist called James Morningdale, quite talented in his way. He carried on his work in a remote part of Scotland, where I suppose he thought he'd attract less attention. What he wanted was to offer people the possibility of having children with enhanced characteristics. Superior intelligence, superior athleticism, that sort of thing.... It reminded people, reminded them of a fear they'd always had. [1, p. 259].

This Morningdale idea is based on eugenics that was originally coined in 1883 by an English scientist, Francis Galton, who was influenced by his cousin, Charles Darwin, the founder of the theory of evolution.

Eugenics became accepted at the beginning of the twentieth century, yet the most horrified example is the Holocaust by the Nazis. The "fear they'd always had" was the wartime segregation and mass murder of the Jews, the Romas, the Polish, as well as handicapped, especially mentally retarded 
people, Parkinson's disease patients, homosexuals, criminals, and other people who were labelled as the unqualified. However, eugenic was born and developed in England and then in the United States, and eventually influenced German eugenics. The most controversial strategy based on eugenics is, as Kevles points out, that sterilization started at the beginning of the 1930's and its tragedy has not recognized. The clones in Never Let Me Go are encouraged to have sex since it is believed that sex helps to keep healthy organs for donations, yet they learn in their sex education they are deprived of reproduction function: "Then there was the whole business about our not being able to have babies. Miss Emily used to give a lot of the sex lectures herself, ...” [1, p. 82]. In a test tube, the clones are sterilized so that they need to know that they are different from the people outside and do not have the same reason to have sex.

The Holocaust is largely known as the mass murder of the Jews, yet this official murder of the handicapped people called Aktion T4 Euthanasia Program started earlier in 1939 and was officially called off by Hitler due to the sharp criticism by the public and Catholic churches: therefore, the carbon monoxide gas facility that was used in Hadamar Mental Hospital, where more than 10,000 patients were killed, was moved to Poland and was used for killing the Jews [6]. Aktion T4 was the starting point of the Holocaust. Even after the official ending of Aktion T4, the doctors could kill those who they considered were unqualified. After World War II, eugenics was connected with the Holocaust, so that in most of the countries abandoned their national policies of social welfare based on eugenics and currently Singapore is the only nation to employ eugenic-based national policy. However, Bryan Appleyard points out that our future society will apply eugenic solely because the cutting-edge technology and medical science such clone, genetic engineering, and genomic will lead to the eternal reproduction of human lives, more effective life-prolonging treatment [7].

Within his story of clones, Ishiguro mentions the postwar situation regarding eugenic-based clone donations as a critical case of highly-developed science in modern era, and at the same time criticizes that the ongoing scientific discoveries and developments will result in the most horrified case of conflicting human lives in the future.

\section{The Buried Histories and Stories}

Like the clone production in Never Let Me Go, the cognitive impairment in The Buried Giant is realistic from our contemporary view of aging, yet it is on purpose described metaphorical and illusionary in respects of being dramatized in the legendary age and landscape. Moreover, the protagonists, the aging couple called Alx and Beatrice, are confronted with segregation and exclusion in the region of the same racial and cultural dwellers: "this elderly couple, lived on the outer fringe of the warren, where their shelter was less protective from the elements and hardly benefited from the fire in the Great Chamber where everyone congregated at night" [2, p. 5]. Their situations are neither evident nor properly informed and even both Alx and Beatrice cannot find the reason why they are subtly segregated from the others and are concentrated in the invisible imprisonment.

Oblivion shadows this harsh conditions of segregation and imprisonment. Both Alx and Beatrice are not aware of this ill treatment or even discrimination because they suffer cognitive impairment, that is, the mist in the novel. Alx is in the middle of confusions:

He wondered how thick the mist would be that morning, and if as the dark faded, he would see it had seeped through the cracks right into their chamber. But then his thoughts drifted away from such matters, back to what had been preoccupying him. Had they always lived like this, just the two of them, at the periphery of the community? [2, p. 7].

Human brains struggle, yet their oblivion cannot be cured: both Alx and Beatrice forget the past incidents including their son's missing from home, and they even do not remember whether they had once their son. Their journey to find their son is quite like poriomania, the habit of wondering about. Even in our science-oriented era, neuroscience is most controversial because it cannot be fully understood. During their journey, they gradually remember what have happened to them and their son. Due to the lack of uncertain memory and right judgement, their journey turns to be the hard path to accept the reality: their own sins, immoral behaviors, and their breakups. Both public and private memories are gradually distinct enough for them to be tortured by their direct involvements in the misdeeds. Oblivion plays a role to shelter them from the public and private criticism on them, yet it increases and leaves doubt about the meaning of life.

Both Never Let Me Go and The Buried Giant are challenging works in which Ishiguro ventured into the transfiguring human consciousness about life and death in the twentieth and twenty-first centuries.

\section{DISCOVERED AND RETOLD MEMORIES IN TSUSHIMA'S YAMANEKO DOMU AND KARINO JIDAI}

\section{A. Discoveries, Trauma, and History}

In Tsushima's novels, the past and memories play leading parts in delineating the traumatic experience of World War II, postwar conflicts and confusions during the Occupation Era, Japan's economic and social transformations in the 1950's, the 1960's and 1970's, Japan's globalization, and such natural and nuclear chaos as 3/11. Yamaneko Domu signifies the shadowy part of this transformation and globalization by presenting to us the orphans and their lost selves and sense of confidence. Followed by her previously-published novel, Yamaneko Domu as a post 3/11 literature, Karino Jidai is also a highly-challenged work because it was completed during her illness and published as her posthumous novel after her death. In other words, Yamaneko Domu represents Tsushima's last and uppermost message in this rapidly and dangerously transfiguring and globalized world of endless and absurd catastrophes.

\section{B. Quaking History after 3/11}

As a literature of 3/11, Tsushima's Yamanako Domu possesses the multilayered corruptions of the society and the people's lives after World War II from the perspectives of several orphans who are born of American soldiers and Japanese women during the Occupation era. Whether they are adopted in Japan or overseas, those abandoned children 
without the sense of roots and identity have different connections with Japan. Their return to Japan due to $3 / 11$ counts for their concerns about their own country in spite of their hatred to and anger against it. There are distinct two kinds of themes: the dark side of US-Japan relationship; and the economically stratified society and radioactive contamination [8, p. 82]. The existence of those orphans of Japanese and American biological parents represents the contradiction, disagreement, and conflicts of ideologies that have repeatedly taken place in Japan till our contemporary era that is threatened by the sudden enormous natural catastrophes, the manmade disaster of nuclear plants and testing, and unexpected and inhumane acts.

Those orphans' stories in Yamaneko Domu are shifted between the time they were taken to the orphanage for the children born of American GIs and Japanese women and the time when they encounter $3 / 11$ in different places on the globe. Those children suffer both racial and patriarchal conflicts and they are considered as racially inferior and socially unacceptable after the war. The postwar Japanese society cannot accept those children in respects of eugenics. The gap in their lives is filled with both their changing private lives such as adoption, job, love affair, marriage, child-birth, and death; and the social and political changes on the globe such as Korean War, Civil Rights Movement, Vietnam War, the Oil Shock, the assassination of Indira Gandhi in 1984, Gulf War, 9/11, and Iraq War.

Being outcast and discriminated, those war orphans are captured by the sense of estrangement. Dispersing across the globe, those children are connected with one woman called Mam, the principal of the orphanage who sacrifices herself to protect them; and also with one incident that one of the orphans named Mitchy at seven in her orange skirt was drawn to death in the nearby pond. Because the other orphans testified that Ta-bo, a neighbor boy of the single mother household, had pushed Mitchy to the pond, Ta-bo became a murder suspect. Ta-bo and his mother who suffer from poverty, isolation, and neglect overshadow and even threaten Mam and the orphans throughout their lives. The myth of the murder is never solved, shown in a series of murders of women in orange. Mam dies of cancer, while Ta-bo commits suicide: their death represents the loss of security and reassurance.

The discovered story and retold memories of those orphans as outsiders of the society embodies the unconscious violations to what are cruelly considered unqualified and unwanted children as victims of invisible eugenics in postwar Japan.

\section{Hunting the "Unqualified"}

In a multilayered perspective, Tsushima is dedicated to compiling her last novel, Karino Jidai which encodes the long untold stories of the voiceless people called the "unqualified." In revealing the untold story of a mentally retarded child and his family, Tsushima encodes the international and national policy and the public cruel treatment of the "unqualified" people. Especially, Tsushima encodes the wrong ideology of Aktion T4 Nazi Euthanasia Program that means sending handicapped people to the gas rooms to terminate their lives and also those of Hitler Youth as a representative organization by physically and mentally healthy, pure-Aryan, politically-inclined young people. Those discoveries leave the wounds to the people who are victimized under the wrong ideological ideas.

It is important to notice that Nazi's eugenic theory leads to both euthanasia of unqualified people and birth of qualified people [9]. Since Hitler was convinced that wars give us a perfect opportunity to erase the incurable patients, both mental and physical handicapped people were targeted as the worthless existence to threaten the pure blood of the Aryan people. Even though there was a demonstration against Aktion T-4 program in 1941, the Nazis secretly continued this program till the end of World War II so that approximately 20 million handicapped people were killed between 1940 and 1954 [10]. This T-4 program became a model or even an experiment of the mass massacre of the Jews and the Romas especially between 1941 and 1942. At the same time, Hitler founded a series of organizations including Hitler Youth in order to "possess as a precondition of success a fundamentally powerful organizational basis under dictatorial control with mass propaganda capability" [11, p. 21]. Especially Hitler Youth had its members who passed the pure Aryan examination, received Spartan trainings, were engaged in hard works and sports, brainwashed into believing Nazi ideology, and demanded absolute obedience; consequently, those HY members took it granted that Aktion T4 and the Holocaust are absolutely right [12].

As the counterpoint of Aktion T4 is Hitler Youth in Nazi's eugenic theory, that of Down syndrome in postwar Japan is the growing young generation who aim at the establishment of highly educated and financially independent lives especially in the 1950's and the 1960's during Japan's rapid economic development. The protagonist of Karino Jidai, Emiko, represents Tsushima's alter ego who spends her childhood days after World War II, with her mother Hiroko and her brother Kotaro. Her parents married after the war and had two children, Kotaro and Emiko, yet Kotaro turned to be mentally retarded immediately after his birth. Though not clearly defined, Kotaro might suffer Down syndrome. Emiko's father Ryotaro died when his son was only two, leaving all the burden to widowed Kazumi. When Kotaro died at fifteen, Kazumi and Emiko were left alone themselves as a single-motherhood condition without any male family member. Emiko's discovery and thorough understanding over Kazumi's agony over these experiences especially about Kotaro always reflect her vague postwar memory and also her mother's prewar memory in which something like "unqualified" is connected with euthanasia.

German eugenic-based national policy is not only the product of Nazi fascism and totalitarianism, but also the representative of the international trend in the early 1900's. It was only in 1996 when Japanese government officially abolished the Eugenics Protection Law and renamed it as the Maternity Protection Law. Even though eugenics was legally banned, there still exists the issue of abortion of the "unqualified" babies, especially those of Down syndrome [13, p.63]. In an international sphere, moreover, eugenics was what the twentieth century embraces and was emerged into the national laws.

Japanese fascism also possessed the strong inclination to 
protect the superiority of purified Japanese blood and excluded the minorities such as the Okinawans and the Ainus. In a colonial perspective, Japanese Empire invaded into the other Asian countries, oppressed them as the inferior races, and forced them to learn Japanese language and to have Japanese names. In this respect, the Japanese fascists were engaged in killing the "unqualified" people as the Nazis did.

This eugenic-based strategy has a national tendency since it was applied especially to the patients of the Hansen's disease. In 1907, Japanese government issued the law and began to relocate and imprison those patients in national sanatoriums: in 1915, furthermore, the government began to sterilize the sufferers from Hansen's disease [13, p. 63]. Because of the lack of the precise information and knowledge of Hansen's disease, it was believed that the disease is infected and also inherited to the babies. This sterilization was carried out not legally but voluntarily; within the closed and confined space of the segregated sanatorium, it was possible to advance the sterilization as a practice and also an experiment [13, p.66-67].

Emiko's personal vague memory and discovery of victimization concealed in a collective memory correspond to the obscurity and unauthenticity of recorded history and a wrongly-input collective memory. Emiko's discovery of a consistent prejudice to her handicapped brother and her mother is intertwined with that to her own, and ultimately related with such historical incidents as the Vietnam War, the assassinations of Martin Luther King, Jr', President Kennedy, and Malcom X. These incidents are studied by Emiko in her high school days when she was struggling with the sense of identity and the goal of her life. Emiko's uncle Eiichiro a scholar and his family who migrated to the United States and established their lives in the postwar period are critically juxtaposed by Kazumi and her family. Eiichiro's success as an established professor in the US and his family's luxurious lifestyle embody the other side of the postwar society. Even though Eiichiro and his family coexist the problematic side of the US, they are liberated from the conventions and family strives in Japan.

Emiko's learnings on the Nazis and the Jewish eminent scholars who were killed during the war are connected with her learnings on her family history, especially Kotaro. The end of the novel consists of the historical reaffirmation of T4 program, 3/11, and paradoxically of Eiichiro's cognitive impairment due to his aging. At the end of his life, Eiichiro has been close to Kotaro whom Eiichiro ignores and neglects. In his dementia, Eiichiro makes a speech against nuclear plants. It is ironical that Karino Jidai expresses the merciful hunting of human lives as well as human dignity.

Tsushima's two novels outline the process of discovering the long-forgotten stories and histories as the evidence of the current violations. The traumatic experiences that leave the wounds to the victims and their related people are retold as a collective memory in Tsushima's fiction.

\section{CONCLUSION}

The crisis in the contemporary society is the target for all the artists because there are horrified yet invisible themes, especially the corruption of the dignity of life. The dignity of life is a challenging theme throughout the modern and contemporary history which is blessed with remarkable scientific and technological developments, yet at the same time it is entirely tested and even contested, represented by eugenics, against those unavoidable developments. Even after the entire decline of Nazi's eugenics strategy represented by Holocaust, there appears the controversial issues related to eugenics such as genetic engineering, infertility treatment, and clone reproduction [14]. In this sense, Ishiguro foresees the future danger of returning the eugenics. His awareness is shared with Tsushima's because these two writers are always concerned about the dignity of life in the middle of catastrophes.

Both Ishiguro and Tsushima are global writers in respects of their endless endeavor to discover and express their own beliefs. Their voices against violations that are especially resulted from the wrong ideology and nation of eugenics are echoing in their fiction.

\section{ACKNOWLEDGMENT}

Sponsor and financial support acknowledgment is placed in the unnumbered footnote on the first page.

\section{REFERENCES}

[1] K. Ishiguro, Never Let Me Go, London: Farber \& Farber, 2011.

[2] K. Ishiguro, The Buried Giant, London: Farber \& Farber, 2015.

[3] Y. Tsushima, Yamaneko Domu [Wildcat Doom], Tokyo: Kodansha, 2013.

[4] Y. Tsushima, Karino Jidai [The Age of Hunting], Tokyo: Bungeishunju, 2016.

[5] Y. Teo, Kazuo Ishiguro and Memory, London: Palgrave Macmillan, 2014.

[6] H. G., Gallagher, By Trust Betrayed: Physician, and the License to Kill the Third Reich, Saint Petersburg, FL: Vandamere, 1995.

[7] B. Appleyard, Brave New Worlds, New York: Viking, 1998.

[8] Y. Negishi, "Joseisakkano Fukushima-Tsushima Yuko Yamaneko Domu to Kanehara Hitomi Motazarumono [Fukushima for Women Writers - Tsushima Yuko's Yamaneko Dome and Kanehara Hitomi's The Unpossessed]," Social Literature, no. 43, pp. 81-92, 2016.

[9] D. J, Kevles, In the Name of Eugenics: Genetics and the Uses of Human Heredity, New York: Knopf, 1985.

[10] United States Holocaust Memorial Museum, Washington, DC.

[11] P. D. Stachura, Nazi Youth in the Weimar Republic, Santa Barbara: Clio, 1975.

[12] B. R. Lewis, Hilter Youth, London: Amber, 2000

[13] Y. Fujino, Nihonfashizumu to Yuseigaku [Japanese Fascism and Eugenics], Kyoto: Kamogawa, 1998.

[14] M. B. Adams, The Wellborn Science: Eugenics in Germany, France, Brazil, and Russia, Oxford: Oxford UP, 1990.

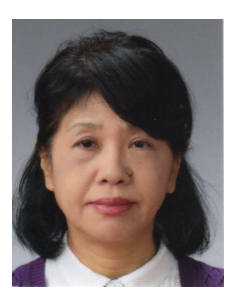

Masami Usui received her BA and MA from Kobe College, Japan, and her second MA and PhD from Michigan State University. After teaching at Hiroshima University, she is currently Professor of English and chair of graduate school of English at Doshisha University, Kyoto, Japan. She has been doing her research and writings on Virginia Woolf and women writers, Asian American literature and culture, and popular culture. She published papers in Japan, England, Korea, USA, Germany, etc., and contributed to Virginia Woolf and War (1991), Asian American Playwrights (2002), Literature in English: New Ethnical, Cultural, and Transnational Perspective (2013), Virginia Woolf and December 1910 (2014), etc. Along with MLA, International Virginia Woolf Conference, International Popular Culture Conference, American Studies Association Conference, she has presented her papers in English at Academia Senica in Taiwan, ASAK and KAFSEL in Korea, MESEA in Hungary, CISLE in Canada, International Conference on Asian 
American Expressive Culture in Beijing, China, International Conference: The Cultural Translation and East Asia, Bangor, England, The $20^{\text {th }}$ Annual Conference of EALA in Taiwan, and International PC/ACS Conference in Poland, and the 2014 International Symposium on Cross-Cultural Studies, Taiwan, International Conference: English Studies as Archive and as Prospecting the $80^{\text {th }}$ Anniversary Conference, University of Zagreb, Zagreb,
Croatia, The $3^{\text {rd }}$ International Conference on Linguistics, Literature and Culture 2014, Penang, Malaysia, Expanding the Parameters of Asian American Literature: An International Conference, Xiamen University, Xiamen, Fujian, China, The CISLE 2015, Gottingen University, Germany, The ICLLL in Taichung, and The 2016 MLA International Symposium in Dusseldorf, Germany, etc. 